\title{
Crystal structure and revision of the chemical formula of georgiadesite, $\mathrm{Pb}_{4}\left(\mathrm{AsO}_{3}\right) \mathrm{Cl}_{4}(\mathrm{OH})$
}

\author{
M. PASERo* AND D. VACChIANO
}

Dipartimento di Scienze della Terra, Università di Pisa e CNR-CSGSDA, Via S. Maria 53, I-56126 Pisa, Italy

\section{ABSTRACT}

The crystal structure of the rare secondary lead mineral georgiadesite has been solved from singlecrystal X-ray diffraction data $(R=0.071)$. The structure can be visualized in terms of alternating puckered (100) layers of $\left[\mathrm{Pb}_{6}\right]$ octahedra and $\left[\mathrm{Pb} \phi_{8}\right]$ bicapped trigonal prisms $(\phi=$ generic anion). Lead also occurs in irregular, lopsided polyhedra. This structural study shows unambiguously that arsenic occurs as $\mathrm{As}^{3+}$ and not as $\mathrm{As}^{5+}$. The chemical formula of georgiadesite has therefore been revised, on structural grounds, to $\mathrm{Pb}_{4}\left(\mathrm{AsO}_{3}\right) \mathrm{Cl}_{4}(\mathrm{OH})$.

KEYWORDs: georgiadesite, crystal structure, lead halides, lone-pair effect, Laurion (Greece).

\section{Introduction}

Georgiadesite is an exceedingly rare mineral, a lead arsenite-hydroxychloride from Laurion, Attica, Greece, discovered by Lacroix and de Schulten (1907). In this locality georgiadesite occurs as a secondary lead mineral within Athenian-age slags; according to the few other descriptions reported in the literature (Kohlberger, 1976; Rewitzer and Hochleitner, 1989), georgiadesite is one of the rarest slag minerals, and is found at Laurion associated with other minerals of similar genesis such as paralaurionite, laurionite, phosgenite, fiedlerite, matlockite, boleite, cumengite, nealite, anglesite and cerussite. Lacroix and de Schulten (1907) proposed the chemical formula $\mathrm{Pb}_{3}\left(\mathrm{AsO}_{4}\right) \mathrm{Cl}_{3}$ for georgiadesite. More recently, georgiadesite was re-examined and new chemical data were obtained from the type specimen (Rouse and Dunn, 1983). Electron microprobe analyses suggested the formula $\mathrm{Pb}_{16}\left(\mathrm{AsO}_{4}\right)_{4} \mathrm{Cl}_{14} \mathrm{O}_{2}(\mathrm{OH})_{2}$ [or, alternatively, $\left.\mathrm{Pb}_{16}\left(\mathrm{AsO}_{4}\right)_{4} \mathrm{Cl}_{14}(\mathrm{OH})_{6}\right]$. In all of these formulae the valence state of arsenic is given as $\mathrm{As}^{5+}$. Other formulae were suggested by Rouse and Dunn (1983), with other valence states such as $\mathrm{As}^{3+}$

\footnotetext{
*E-mail: pasero@dst.unipi.it
}

and/or $\mathrm{Pb}^{4+}$, but were considered unlikely, because $\mathrm{Pb}$ and As typically occur at Laurion as $\mathrm{Pb}^{2+}$ and $\mathrm{As}^{5+}$. This is true for $\mathrm{Pb}$. For $\mathrm{As}$, however, those authors were probably misled by the incorrect assignment of $\mathrm{As}^{5+}$ for the mineral nealite, found intimately associated with georgiadesite at Laurion (Dunn and Rouse, 1980). A structural study confirmed that nealite contains $\mathrm{As}^{3+}$ (Giuseppetti et al., 1993).

\section{Experimental}

Our X-ray diffraction (XRD) study was carried out on crystal fragments extracted from a georgeadesite-bearing slag from Laurion. Crystals of georgiadesite are extremely rare and typically occur as parallel intergrowths. After repeated crushing of an aggregate, and preliminary examination by Weissenberg photographs, a very small single crystal of georgiadesite was eventually obtained (dimensions $0.02 \times 0.05$ $\times 0.08 \mathrm{~mm}$ ).

A set of intensity data was collected from this crystal using a conventional Siemens four circle diffractometer. The operating conditions were: $50 \mathrm{kV}, 40 \mathrm{~mA}$, radiation Mo- $K \alpha, \lambda=0.71069 \AA$, scan mode $\theta-2 \theta$, scan width (in $\theta$ ) $\pm 0.57^{\circ}$, scan speed $2 \% \mathrm{~min}, 2 \theta_{\max }=50^{\circ}$. Georgiadesite is monoclinic, $P 2_{1} / c$, with the following unit-cell parameters obtained through a least-squares fit of 
a set of accurately centred reflections: $a=$ 13.765(3), $b=7.896(3), c=10.804(3) \AA, \beta=$ $102.57(1)^{\circ}$. These agree with the values obtained by Rouse and Dunn (1983) from the powder pattern. A total of 2831 intensities were measured $(-16 \leqslant h \leqslant 1,-1 \leqslant k \leqslant 9,-12 \leqslant l \leqslant 12)$, which were reduced to a set of 826 observed (i.e. with $\left.F_{\mathrm{o}}>6 \sigma\left[F_{\mathrm{o}}\right]\right)$ independent squared amplitudes, after correction for Lorentz and polarization factors, and for absorption effects through $\psi$ scan measurements on 12 reflections.

The crystal structure of georgiadesite was solved using direct methods (SHELXS-86; Sheldrick, 1985) and refined against squared $F$ values (SHELXL-93; Sheldrick, 1993) to the following values: R1 (conventional $R$ factor) $=$ 0.0712 , wR2 (weighted $R$ on $F^{2}$ ) $=0.1776$, and $S$ $($ goodness of fit $)=1.040$. Anisotropic refinement was completed for all atoms with the exception of $\mathrm{O}$ which were refined isotropically. The $\mathrm{H}$ atom was placed in a calculated position and held fixed by constraints. The maximum positive and negative heights in the final difference Fourier synthesis were +3.0 and $-3.1 \mathrm{e} / \AA^{3}$, respectively. As expected, all highest residuals are located near the $\mathrm{Pb}$ atoms. Considering the small size of the crystal (most of the 'observed' reflections were actually very weak), and the large absorption correction, the results of the refinement can be considered adequate for us to understand the structural features of georgiadesite.

\section{Description of the structure}

Final fractional coordinates and equivalent isotropic displacement parameters are reported in Table 1, while bond distances and the bond valence balance are reported in Table 2 .

The most remarkable result of the single-crystal study of georgiadesite is the recognition of the correct valence state of As, which is $\mathrm{As}^{3+}$ and not $\mathrm{As}^{5+}$, leading to the chemical formula $\mathrm{Pb}_{4}\left(\mathrm{AsO}_{3}\right) \mathrm{Cl}_{4}(\mathrm{OH})$, with $Z=4$.

The four independent $\mathrm{Pb}$ atoms show three different coordinations, in both the number of coordinating anions and the geometry of the polyhedra. $\mathrm{Pb} 1$ is linked to one $\mathrm{O}$ and five $\mathrm{Cl}$ atoms, in a distorted octahedral coordination. $\mathrm{Pb} 2$ and $\mathrm{Pb} 4$ have similar coordination and can be described together: they are linked to three $\mathrm{O}$ atoms and two $\mathrm{Cl}$ atoms which form irregular and almost 'open' polyhedra. In both cases one or two additional chlorine anions occur at a distance of $\sim 3.50 \AA$ from $\mathrm{Pb}$. However, the distance and the position of these $\mathrm{Cl}$ atoms with respect to the cation and the other anions led us to consider their interaction with $\mathrm{Pb}$ as negligible. Lead atoms are strongly lopsided with respect to the anions, due to the stereoactive lone-pair effect. $\mathrm{Pb} 3$ is linked to four $\mathrm{O}$ atoms and four $\mathrm{Cl}$ atoms, which form a distorted bicapped trigonal prism (Fig. 1). Arsenic is linked to three oxygens, which give rise to a trigonal pyramid together with the cation which

TABLE 1. Final positional and displacement parameters for georgiadesite. The coordinates for $H$ have been calculated (see text for explanation).

\begin{tabular}{lccccccccc}
\hline Atom & $x$ & $y$ & $z$ & $U_{11}$ or $U$ & $U_{22}$ & $U_{33}$ & $U_{23}$ & $U_{13}$ & $U_{12}$ \\
\hline $\mathrm{Pb} 1$ & $0.5853(2)$ & $0.2214(5)$ & $0.8688(3)$ & $0.032(1)$ & $0.040(2)$ & $0.037(1)$ & $0.001(2)$ & $0.006(1)$ & $0.001(2)$ \\
$\mathrm{Pb} 2$ & $0.8126(2)$ & $0.0978(5)$ & $0.6502(3)$ & $0.044(2)$ & $0.042(2)$ & $0.034(2)$ & $-0.007(2)$ & $0.007(1)$ & $0.001(2)$ \\
$\mathrm{Pb} 3$ & $0.0556(2)$ & $0.2422(5)$ & $0.4831(2)$ & $0.038(1)$ & $0.039(2)$ & $0.038(1)$ & $-0.001(2)$ & $0.007(1)$ & $0.003(2)$ \\
$\mathrm{Pb} 4$ & $0.3346(2)$ & $0.2428(5)$ & $0.5552(3)$ & $0.034(1)$ & $0.042(2)$ & $0.041(2)$ & $-0.002(2)$ & $0.005(1)$ & $-0.004(2)$ \\
$\mathrm{As}$ & $0.8001(6)$ & $0.048(1)$ & $0.3459(7)$ & $0.036(4)$ & $0.031(5)$ & $0.036(4)$ & $0.008(4)$ & $0.009(3)$ & $0.007(4)$ \\
$\mathrm{Cl1}$ & $0.212(1)$ & $0.556(3)$ & $0.557(2)$ & $0.04(1)$ & $0.04(1)$ & $0.06(1)$ & $0.00(1)$ & $0.013(9)$ & $0.01(1)$ \\
$\mathrm{Cl} 2$ & $1.003(1)$ & $-0.060(4)$ & $0.781(2)$ & $0.04(1)$ & $0.10(2)$ & $0.04(1)$ & $0.00(1)$ & $0.010(9)$ & $-0.01(1)$ \\
$\mathrm{Cl3}$ & $0.420(1)$ & $0.442(3)$ & $0.844(3)$ & $0.04(1)$ & $0.07(2)$ & $0.05(1)$ & $0.01(1)$ & $0.007(9)$ & $0.00(1)$ \\
$\mathrm{Cl} 4$ & $0.593(2)$ & $0.099(4)$ & $1.129(2)$ & $0.07(1)$ & $0.07(2)$ & $0.03(1)$ & $0.00(1)$ & $0.010(9)$ & $0.02(2)$ \\
$\mathrm{O} 1$ & $0.695(3)$ & $0.060(6)$ & $0.436(3)$ & $0.015(9)$ & & & & & \\
$\mathrm{O} 2$ & $0.901(3)$ & $0.055(8)$ & $0.486(4)$ & $0.03(1)$ & & & & & \\
$\mathrm{O} 3$ & $0.792(4)$ & $-0.173(7)$ & $0.347(4)$ & $0.03(1)$ & & & & & \\
$\mathrm{O} 4$ & $0.200(4)$ & $0.201(7)$ & $0.390(5)$ & $0.04(1)$ & & & & & \\
$\mathrm{H}$ & 0.192 & 0.267 & 0.313 & & & & & & \\
\end{tabular}




\section{STRUCTURE AND CHEMISTRY OF GEORGIADESITE}

TABLE 2. Selected bond distances in georgiadesite (in $\AA$; first row), and corresponding bond valences (in v.u.; second row, in italic) computed according to Brese and O'Keeffe (1991). The average esd values on bond distances are \pm 0.02 for distances involving $\mathrm{Cl}$ and \pm 0.05 for distances involving $\mathrm{O} . \Sigma_{\mathrm{v}} \mathrm{a}$ and $\Sigma_{\mathrm{v}} \mathrm{c}$ are the bond valence sums for anions and cations, respectively.

\begin{tabular}{|c|c|c|c|c|c|c|}
\hline & $\mathrm{Pb} 1$ & $\mathrm{~Pb} 2$ & $\mathrm{~Pb} 3$ & $\mathrm{~Pb} 4$ & As & $\Sigma_{v} \mathrm{a}$ \\
\hline $\mathrm{Cl1}$ & $\begin{array}{l}3.02 \\
0.27\end{array}$ & $\begin{array}{l}3.27 \\
0.14\end{array}$ & $\begin{array}{l}3.27 \\
0.14\end{array}$ & $\begin{array}{l}2.99 \\
0.29\end{array}$ & & 0.84 \\
\hline $\mathrm{Cl} 2$ & & $\begin{array}{l}2.96 \\
0.31\end{array}$ & $\begin{array}{l}3.14+3.24+3.30 \\
0.19+0.15+0.12\end{array}$ & & & 0.72 \\
\hline $\mathrm{Cl} 3$ & $\begin{array}{l}2.83+3.18 \\
0.44+0.17\end{array}$ & & & $\begin{array}{l}3.14 \\
0.19\end{array}$ & & 0.80 \\
\hline $\mathrm{Cl} 4$ & $\begin{array}{l}2.95+2.97 \\
0.32+0.30\end{array}$ & & & & & 0.62 \\
\hline O1 & $\begin{array}{l}2.31 \\
0.59\end{array}$ & $\begin{array}{l}2.53 \\
0.32\end{array}$ & & $\begin{array}{l}2.43 \\
0.42\end{array}$ & $\begin{array}{l}1.91 \\
0.72\end{array}$ & 2.05 \\
\hline $\mathrm{O} 2$ & & $\begin{array}{l}2.38 \\
0.48\end{array}$ & $\begin{array}{l}2.42+2.60 \\
0.43+0.27\end{array}$ & & $\begin{array}{l}1.83 \\
0.90\end{array}$ & 2.08 \\
\hline $\mathrm{O} 3$ & & & $\begin{array}{l}2.52 \\
0.33\end{array}$ & $\begin{array}{l}2.30 \\
0.60\end{array}$ & $\begin{array}{l}1.75 \\
1.11\end{array}$ & 2.04 \\
\hline O4 & & $\begin{array}{l}2.40 \\
0.46\end{array}$ & $\begin{array}{l}2.43 \\
0.42\end{array}$ & $\begin{array}{l}2.31 \\
0.59\end{array}$ & & 1.47 \\
\hline$\Sigma_{v} \mathrm{c}$ & 2.09 & 1.71 & 2.05 & 2.09 & 2.73 & \\
\hline
\end{tabular}

represents one of the vertices: this is the typical coordination for $\mathrm{As}^{3+}$; if it was $\mathrm{As}^{5+}$ it would have tetrahedral coordination.

A general view of the crystal structure of georgiadesite is shown in Fig. 2, as seen along $c$. The structure can be conveniently described as a regular alternation of two basic modules formed by $\mathrm{Pb} 1$ - and $\mathrm{Pb} 3$-centred polyhedra, respectively. $\mathrm{Pb} 1$-centred octahedra form puckered (100) layers by corner-sharing, whereas $\mathrm{Pb} 3$-centred bicapped trigonal prisms form similar, but less undulated, layers by corner- and edge-sharing. The stacking of these layers, which share $\mathrm{Cll}$ atoms, gives rise to structural cavities, which are filled by lowercoordinated $\mathrm{Pb} 2, \mathrm{~Pb} 4$ and $\mathrm{As}$.

The electrostatic bond valence balance (Table 2) shows that, among the four independent oxygen atoms, $\mathrm{O} 4$ actually belongs to a hydroxyl group, and that a hydrogen bond of the kind $\mathrm{O}-\mathrm{H} \cdots \mathrm{Cl}$ seems likely, the chlorine anions all being undersaturated. The position of the $\mathrm{H}$ atom was inferred by analogy with other lead hydroxychlorides, e.g. paralaurionite, $\mathrm{PbCl}(\mathrm{OH})$ (Merlino et al., 1993), in which the oxygen belonging to a $(\mathrm{OH})$ group is linked to three $\mathrm{Pb}$ atoms, and the $\mathrm{H}$ points away from the plane defined by the $\mathrm{Pb}$ atoms. The indications of the bond valence balance notwithstanding, it turned out that the $\mathrm{H}$ points towards $\mathrm{O} 3$ rather than towards any $\mathrm{Cl}$. In fact, this is the only reasonable hydrogen bond, in terms of both distances and angles $(\mathrm{O} 4-\mathrm{H} \quad 0.97 \AA, \mathrm{O} 4 \cdots \mathrm{O} 32.77 \AA$, $\mathrm{O} 4-\mathrm{H}-\mathrm{O} 3158^{\circ}$ ), whereas all $\mathrm{O} 4 \cdots \mathrm{Cl}$ distances and $\mathrm{O} 4-\mathrm{H}-\mathrm{Cl}$ angles are unsuitable for hydrogen bonding.

\section{Chemical formula of georgiadesite}

In the only two available chemical analyses of georgiadesite (Lacroix and de Schulten, 1907; Rouse and Dunn, 1983), As is given as $\mathrm{As}_{2} \mathrm{O}_{5}$. Due to the paucity of material, no direct measure of the water content was possible in either case. In light of our structural studies, these analyses have been recalculated with $\mathrm{As}$ as $\mathrm{As}_{2} \mathrm{O}_{3}$; moreover, water has been assumed to be present to give a total of $8 \mathrm{O}+\mathrm{Cl}$ p.f.u., or 3 oxygens and 5 $[\mathrm{Cl}+(\mathrm{OH})]$. The modified analyses are presented in Table 3. From these analyses, the following crystal-chemical formulae are obtained: Rouse and Dunn - $\mathrm{Pb}_{3.92} \mathrm{As}_{1.05} \mathrm{O}_{3.00} \mathrm{Cl}_{3.43}(\mathrm{OH})_{1.57}$; Lacroix and de Schulten $-\mathrm{Pb}_{3.75} \mathrm{As}_{1.17} \mathrm{O}_{3.00} \mathrm{Cl}_{3.77}(\mathrm{OH})_{1.23}$. By comparing these analyses with the ideal formula $\mathrm{Pb}_{4}\left(\mathrm{AsO}_{3}\right) \mathrm{Cl}_{4}(\mathrm{OH})$ which results from 

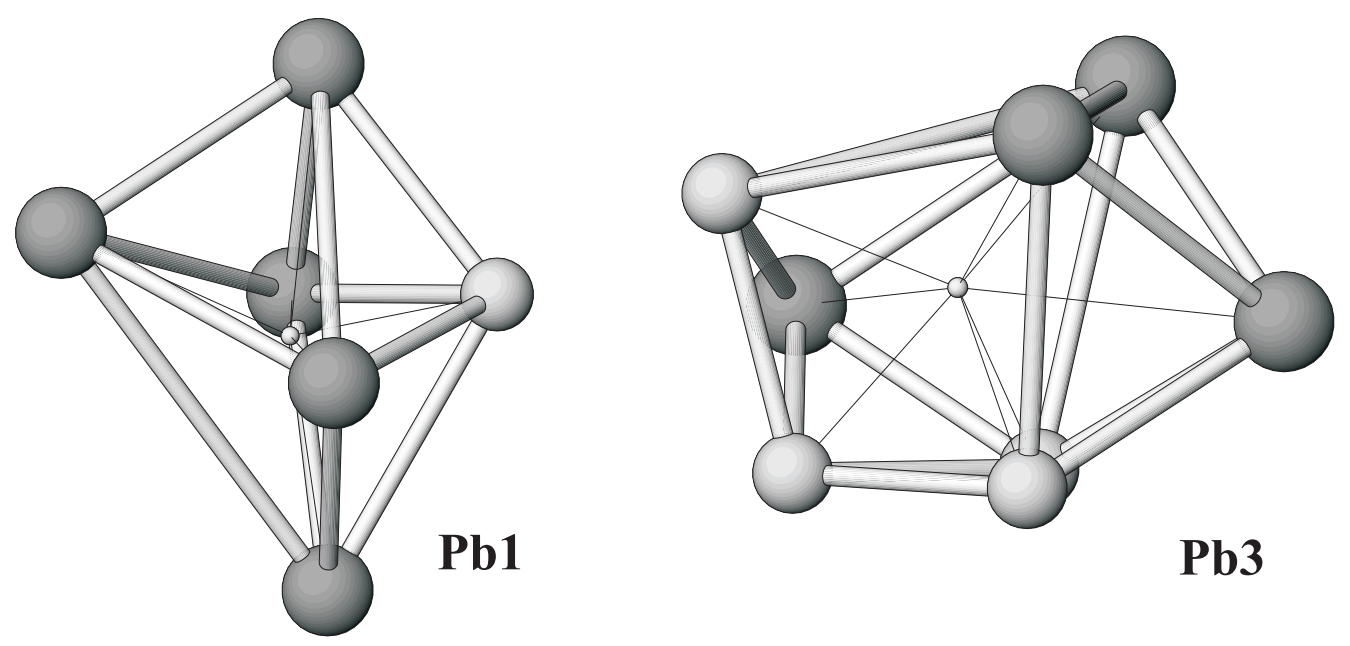

$\mathrm{Pb3}$


FIG. 1. Coordination of the four independent $\mathrm{Pb}$ atoms (small circles): $\mathrm{Pb} 1$, octahedron; $\mathrm{Pb} 3$, bicapped trigonal prism; $\mathrm{Pb} 2$ and $\mathrm{Pb} 4$, irregular lopsided polyhedron. Clorine and oxygen anions are indicated by larger (dark grey) and smaller (light grey) circles, respectively.

our study, we see that the former analysis has a good $\mathrm{Pb} / \mathrm{As}$ ratio, and is low in $\mathrm{Cl}$ : however, a partial substitution of $\mathrm{Cl}$ by $(\mathrm{OH})$ is reasonable from the crystal-chemical point of view. The latter analysis has an almost perfect $\mathrm{Pb} / \mathrm{Cl}$ ratio, but $\mathrm{As}$ is clearly overestimated: possibly because the data

TABLE 3. Chemical data for georgiadesite (wt.\%): (a) original data from literature; (b) recalculated data (present study). See text for explanation.

\begin{tabular}{lcccc}
\hline & \multicolumn{2}{c}{ Rouse and Dunn $(1983)$} & \multicolumn{2}{c}{ Lacroix and de Schulten (1907) } \\
& $\mathrm{a}$ & $\mathrm{b}$ & $\mathrm{a}$ & $\mathrm{b}$ \\
\hline $\mathrm{PbO}$ & 81.3 & 81.3 & 78.05 & 78.05 \\
$\mathrm{As}_{2} \mathrm{O}_{5}$ & 11.2 & - & 12.49 & - \\
$\mathrm{As}_{2} \mathrm{O}_{3}$ & - & 9.64 & - & 10.75 \\
$\mathrm{H}_{2} \mathrm{O}$ (calc.) & - & 1.31 & - & 1.03 \\
$\mathrm{Cl}$ & 11.3 & 11.3 & 12.47 & 12.47 \\
$\mathrm{O}=\mathrm{Cl}$ & -2.6 & -2.55 & -2.81 & -2.81 \\
$\Sigma$ & 101.2 & 101.00 & & 99.49 \\
& & & & \\
\hline
\end{tabular}




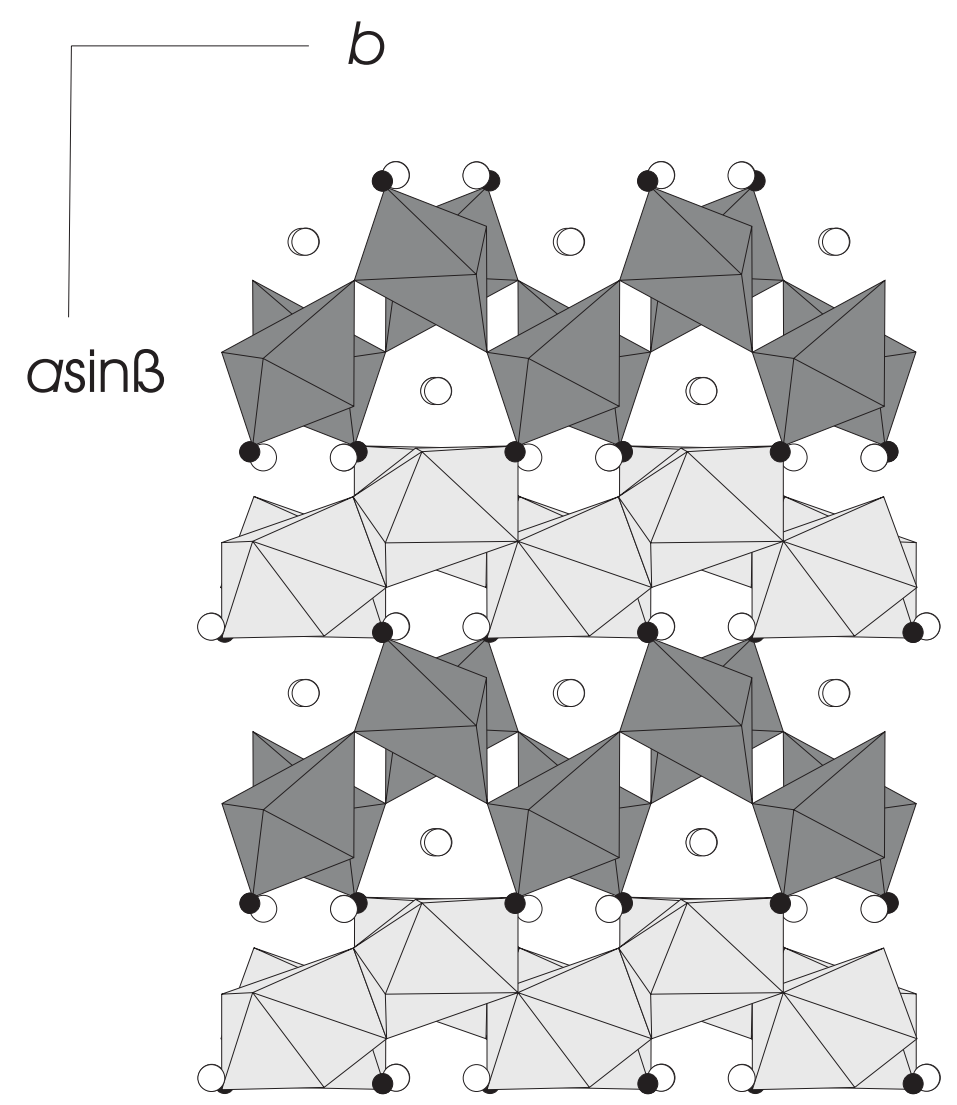

FIG. 2. The structure of georgiadesite, as seen along $c$. Different grey tones denote layers formed by Pb1-centred octahedra (dark grey) and $\mathrm{Pb} 3$-centred bicapped trigonal prisms (light grey), respectively. Open circles indicate $\mathrm{Pb} 2$ and $\mathrm{Pb} 4$, while filled circles represent $\mathrm{As}^{3+}$ cations.

obtained by Lacroix and de Schulten (1907) may have been affected by impurities. The formula $\mathrm{Pb}_{3.92} \mathrm{As}_{1.05} \mathrm{O}_{3.00} \mathrm{Cl}_{3.43}(\mathrm{OH})_{1.57}$ implies a $D_{\text {calc }}$ of $6.31 \mathrm{~g} / \mathrm{cm}^{3}$, in good agreement with the experimental value of $6.3(3) \mathrm{g} / \mathrm{cm}^{3}$ (Rouse and Dunn, 1983).

Following completion of this work, we learned that IR data obtained by Dr Suner (Basel) indicated the possible presence of arsenite groups in georgiadesite (Rewitzer, pers. comm.).

\section{Acknowledgements}

Christian Rewitzer (Furth-im-Wald) is thanked for kindly donating rare georgiadesite-bearing slags from Laurion. Giancarlo Parodi (Paris) provided us with scarcely accessible literature. Marco Tamponi (Pisa) helped in carrying out
SEM/EDS analyses on georgiadesite. Stefano Merlino (Pisa) made useful comments on an earlier draft of the manuscript, and the paper benefited from reviews by Ian Steele (Chicago) and Mario Tribaudino (Torino). Financial support from Centro di Studio per la Geologia Strutturale e Dinamica dell'Appennino (CNR, Pisa) is acknowledged.

\section{References}

Brese, N.E. and O'Keeffe, M. (1991) Bond-valence parameters for solids. Acta Crystallogr., B47, 192-97.

Dunn, P.J. and Rouse, R.C. (1980) Nealite, a new mineral from Laurion, Greece. Mineral. Rec., 11, 299-301. 


\section{PASERO AND D. VACCHIANO}

Giuseppetti, G., Mazzi, F. and Tadini, C. (1993) The crystal structure of nealite: $\mathrm{Pb}_{4} \mathrm{Fe}\left(\mathrm{AsO}_{3}\right)_{2} \mathrm{Cl}_{4} \cdot 2 \mathrm{H}_{2} \mathrm{O}$. Neues Jahrb. Mineral. Mh., 278-88.

Kohlberger, W. (1976) Minerals of the Laurium mines, Attica, Greece. Mineral. Rec., 7, 114-25.

Lacroix, A. and de Schulten, A. (1907) Sur une nouvelle espèce minérale, provenant des scories plombeuses athéniennes du Laurium. C. R. Acad. Sci., 145, 783-85.

Merlino, S., Pasero, M. and Perchiazzi, N. (1993) Crystal structure of paralaurionite and its OD relationships with laurionite. Mineral. Mag., 57, $323-28$.

Rewitzer, C. and Hochleitner, R. (1989) I minerali delle antiche scorie di Laurion, Grecia. Riv. Mineral. It. 21-38 and 83-100.

Rouse, R.C. and Dunn, P.J. (1983) New data on georgiadesite. Mineral. Mag., 47, 219-20.

Sheldrick, G.M. (1985) SHELXS-86. Program for the solution of crystal structures. Univ. Göttingen, Germany.

Sheldrick, G.M. (1993) SHELXL-93. Program for the refinement of crystal structures. Univ. Göttingen, Germany.

[Manuscript received 22 October 1999:

revised 22 March 2000] 